\title{
Effect of Postharvest Methyl Jasmonate Treatment on Early-Matured “Hass" Avocado Fruit Exocarp Colour Development during Ripening
}

\author{
Kingsly Shikwambana ${ }^{1 *}$, Tieho P. Mafeo ${ }^{1}$, Nhlanhla Mathaba ${ }^{2}$ \\ ${ }^{1}$ School of Agriculture and Environmental Sciences, Faculty of Science and Agriculture, University of Limpopo, Sovenga, \\ Polokwane, South Africa \\ ${ }^{2}$ Postharvest Management and Food Security, School of Agricultural Science, Faculty of Agriculture and Natural Sciences, \\ University of Mpumalanga, Nelspruit, South Africa \\ Email: *shikwambanakingsly@gmail.com
}

How to cite this paper: Shikwambana, K., Mafeo, T.P. and Mathaba, N. (2021) Effect of Postharvest Methyl Jasmonate Treatment on Early-Matured "Hass" Avocado Fruit Exocarp Colour Development during Ripening. Agricultural Sciences, 12, 875-887. https://doi.org/10.4236/as.2021.128056

Received: June 2, 2021

Accepted: August 17, 2021

Published: August 20, 2021

Copyright $\odot 2021$ by author(s) and Scientific Research Publishing Inc. This work is licensed under the Creative Commons Attribution International License (CC BY 4.0).

http://creativecommons.org/licenses/by/4.0/

\section{(c) (i) Open Access}

\begin{abstract}
Poor exocarp colour development is a common postharvest problem for early harvested "Hass" avocado fruit during ripening, which affects fruit quality and consumer preference. Therefore, measures to improve "Hass" avocado fruit colour developments are of great importance in the industry. This study investigated the effectiveness of postharvest methyl jasmonate treatment to improve early matured "Hass" avocado fruit exocarp colour during ripening. The results showed that T1 $\left(10 \mu \mathrm{mol} \cdot \mathrm{L}^{-1}\right)$ and T2 $\left(100 \mu \mathrm{mol} \cdot \mathrm{L}^{-1}\right)$ MeJA treatment increased visual colour, and decreased objective colour parameters $\left(\mathrm{L}^{*}\right.$, $C^{*}$ and $h^{9}$ ) during ripening when compared with control fruit. Moreover, MeJA treated "Hass" avocado fruits had lower total chlorophyll content and higher total anthocyanin and cyanidin-3-O-glucoside concentration during ripening. In conclusion, "Hass" avocado fruit post-harvest treated with either T1 $\left(10 \mu \mathrm{mol} \cdot \mathrm{L}^{-1}\right)$ or T2 $\left(100 \mu \mathrm{mol} \cdot \mathrm{L}^{-1}\right)$ MeJA concentration improved exocarp quality attributes such as colour parameters $\left(\mathrm{L}^{*}, C^{*} h^{\circ}\right.$ and visual colour) and pigments (total anthocyanin and cyanidin-3-O-glucoside) during ripening, therefore, can be recommended for avocado fruit.
\end{abstract}

\section{Keywords}

Avocado, Colour, Methyl Jasmonate, Anthocyanin, Cyanidin-3-O-Glucoside

\section{Introduction}

Avocado "Hass" fruit exocarp colour change is a physical ripeness determinant 
and contributes significantly to fruit marketing [1] [2]. However, "Hass" avocado fruit from South Africa has been showing poor exocarp colouration during ripening, therefore, compromising quality fruit and consumer preferences. Mathaba et al. [2] found that "Hass" avocado fruit harvested at early maturity tended to show poor exocarp colour development during ripening. In general, "Hass" avocado fruit changes exocarp colour from green to purple and eventually black, mainly owing to chlorophyll degradation and synthesis and anthocyanin accumulation [1] [3]. In "Hass" avocado fruit exocarp, cyanidin-3$\mathrm{O}$-glucoside is the most abundant specific anthocyanin pigment during ripening [1]. According to Ashton et al. [4], cyanidin-3-O-glucoside is an anthocyanin compound responsible for the purple and black colour development during the ripening of "Hass" avocado fruit. Recently, there is an interest in exploring postharvest treatment which triggers the enhancement of anthocyanin synthesis and accumulation, consequently, leading to improved early matured "Hass" fruit exocarp colour development during ripening.

In this context, methyl Jasmonate (MeJA), a member of the cyclopentanone compound, has been established as a signalling molecule with a positive impact on the colour development of various fruits [5]. In the literature, it has been reported that preharvest or postharvest treatment with MeJA can influence colour development by enhancement of anthocyanin biosynthesis and accumulation in numerous crops including apple [5], pepper [6], grape [7], blueberries [8], eggplant [9] and tomato [10].

In table grapes, postharvest MeJA treatment at $1,0.1$ and $0.01 \mathrm{mM}$ accelerated ripening and increased total phenolic and anthocyanin concentration [11]. In Blackberries, Wang, Bowman [12] showed that preharvest MeJA treatment significantly increased anthocyanin, total phenolic content and antiproliferative activity. Furthermore, Muengkaew et al. [13] found that dipping mango fruit in $\mathrm{MeJA}$ at $80 \mu \mathrm{L} \cdot \mathrm{mL}^{-1}$ resulted in higher phenylalanine ammonia-lyase (PAL) enzyme activity, phenolic compound concentration and higher anthocyanin concentration when compared control fruit. Therefore, the objective of this study was to investigate the effectiveness of postharvest MeJA treatment applied at different concentrations for enhancing anthocyanin concentration, subsequently, to improve purple colour development of early matured "Hass" avocado fruit during ripening.

\section{Materials and Methods}

\subsection{Chemicals}

The methanol, acetonitrile, acetone, acetic acid, potassium chloride, hydrochloric acid, sodium acetate and the standard were cyanidin-3-O-glucoside chloride, were from Sigma-Aldrich chemical, Merck company, South Africa.

\subsection{Plant Materials}

In 2018, avocado fruit "Hass" were harvested from Nico Swart Farm in Kiepersol 
$\left(25^{\circ} 4^{\prime} 0^{\prime \prime} \mathrm{S}, 31^{\circ} 2^{\prime} 0^{\prime \prime E}\right)$, Mpumalanga Province, South Africa at commercial maturity ( $21 \%$ dry matter) by measuring the weight difference of the mesocarp samples taken from the equatorial region of five fruit after harvest. Harvested fruits were transported to the Agricultural Research Council, Tropical and Subtropical Crops (ARC-TSC) $\left(25^{\circ} 45^{\prime} 18^{\prime \prime} S\right.$; $\left.30^{\circ} 96^{\prime} 97^{\prime \prime E}\right)$ postharvest laboratory for MeJA treatment, storage, ripening, evaluation, and analysis.

\subsection{Postharvest MeJA Treatment}

The experiment was conducted as a completely randomized design (CRD) with three replications per treatment. The concentration of MeJA for the treatment $\mathrm{T} 1$ and $\mathrm{T} 2$ were $10 \mu \mathrm{mol} \cdot \mathrm{L}^{-1}$ and $100 \mu \mathrm{mol} \cdot \mathrm{L}^{-1}$, respectively. Ninety fruits for each treatment were dipped in MeJA (Sigma-Aldrich, Chemical, Company, South Africa) solution containing the above concentration in each case for 15 minutes. A control (C) was also included where fruits were not treated with MeJA solution. The treated fruits were allowed to dry at room temperature $\left(25^{\circ} \mathrm{C}\right)$ for 1 hour. Thereafter, treated and control fruits were further packed in plastic crates and stored at $5.5^{\circ} \mathrm{C}$ with relative humidity (RH) of $98 \%$ for 28 days. After 28 days, fruits were removed from cold storage and transferred to room temperature at $25^{\circ} \mathrm{C}$ and allowed to ripen. Five fruits from each treatment were randomly sampled at every evaluation day $\left(0,2,4\right.$ and 6 at $\left.25^{\circ} \mathrm{C}\right)$, subsequently, exocarp tissues of the samples were frozen in liquid nitrogen and cold-stored at $-21^{\circ} \mathrm{C}$ until further analysis.

\subsection{Quality Analysis}

\section{Exocarp Colour}

Avocado fruit "Hass" exocarp colour change was determined subjectively using visual colour (1-emerald green, 2-forest green, 3-olive green, 4-violet; 5-purple, and 6-black) as previously described by Mathaba et al. [2]. The same fruit samples were also used for objective colour assessment using Minolta chromameter (Model: CR-400, Konica Minolta, Sensing Incorporation, Japan) with a white calibration plate $(\mathrm{Y}=87.00 ; \mathrm{x}=0.3146 ; \mathrm{y}=0.3215) \mathrm{L}^{*}=$ lightness, $\mathrm{a}^{*}=$ greenness/redness and $\mathrm{b}^{*}=$ yellowness/blueness and thereafter, converted to chroma and hue angle ( $h{ }^{9}$ ) using the necessary equations according to McGuire [14].

\section{Total Chlorophyll Analysis}

Total chlorophyll was extracted according to Lichtenthaler [15]. Briefly, $0.5 \mathrm{~g}$ powder exocarp tissues were extracted with $10 \mathrm{ml}$ of $80 \%$ acetone, kept on ice for 30 minutes then centrifuged at $6000 \times \mathrm{g}$ for 5 minutes. Total chlorophyll contents were estimated by reading the absorbance at 470, 646 and $663 \mathrm{~nm}$ in a UV-visible spectrophotometer (Jenway, UK). The total chlorophyll contents were calculated by adding $C_{a}$ and $C_{b}$ using equations as follows:

$$
C_{a}=12.25 A_{663}-2.79 A_{646}
$$




$$
C_{b}=21.50 A_{646}-5.10 A_{663}
$$

where $C_{a}$ and $C_{b}$ represents chlorophyll $a$ and $b$.

\section{Total Anthocyanin and Cyanidin-3-O-Glucoside Analysis}

Extraction was done according to Cox, McGhie [1], avocado exocarp tissues were milled to powder under liquid nitrogen and $0.5 \mathrm{~g}$ was extracted with $5 \mathrm{ml}$ of $10 \%$ acetic acid/methanol $(\mathrm{v} / \mathrm{v})$ at room temperature. Therefore, centrifugation at $3000 \times \mathrm{g}$ for 10 minutes, the supernatant was diluted 1:1 with methanol:water:acetic acid (50:50:10, v/v/v). The $\mathrm{pH}$ differential method previously described by Giusti and Wrolstad [16] was used to determine total anthocyanin content. The diluted 1:1 supernatant was filtered through $0.45 \mu \mathrm{m}$ nylon filters into clean vials and diluted with $1 \mu$ of potassium chloride buffer $\left(\mathrm{pH}_{1.0}\right)$ and sodium acetate buffer $\left(\mathrm{pH}_{4.5}\right)$. The mixtures were allowed to settle in the dark for 10 minutes, subsequently, absorbance values of each buffer mixture were measured at 530 and $700 \mathrm{~nm}$ in a UV-visible spectrophotometer (Jenway, UK). The total anthocyanin was calculated using the equation.

$$
\begin{gathered}
\qquad A=\left(A_{510}-A_{700}\right) \mathrm{pH}_{1.0}-\left(A_{510}-A_{700}\right) \mathrm{pH}_{4.5} \\
\text { Total anthocyanin }(\mathrm{mg} / \mathrm{mL})=(A \times M W \times D F) /(\varepsilon \times L)
\end{gathered}
$$

where $A=$ Absorbance, $\varepsilon=$ Cyd-3-glucoside molar absorbance (26,900), $M W=$ anthocyanin 164 molecular weight (449.2), $D F=$ dilution factor, $L=$ cell path length $(1 \mathrm{~cm})$.

Furthermore, cyanidin-3-O-glucoside concentration was measured by highperformance liquid chromatography (HPLC, Agilent Technologies 1200 series gradient, Germany). Extraction of cyanidin-3-O-glucoside from "Hass" exocarp tissues were perfumed following the above-described method by Cox et al. [1]. The HPLC system was equipped with JASCO units (LG-980-02 ternary gradient controller, AS-950 autosampler, and a UV-975 UV/Vis detector). The chromatography column was a Phenomenex AQUA 5u C18 125A 5 um PR-18e $4.6 \times 150 \mathrm{~mm}$ (California, United States of America), maintained at $35^{\circ} \mathrm{C}$. Mobile phases were: (A) 1.5\% $\mathrm{H}_{3} \mathrm{PO}_{4}$ and (B) acetic acid:acetonitrile: $\mathrm{H}_{3} \mathrm{PO}_{4}$ : water $(20: 24: 1.5: 54.5, \mathrm{v} / \mathrm{v} / \mathrm{v} / \mathrm{v})$. The solvent program started with solvent (B) at $20 \%$, increasing to $70 \%$ after 25 minutes, then $90 \%$ at 30 minutes. After 35 minutes, the solvent composition was returned to the initial $20 \%$ solvent (B) and ready for the next injection. The sample injection volume was $2 \mu \mathrm{l}$ and detection was at $530 \mathrm{~nm}$.

\section{Fruit Firmness}

Fruit firmness was measured using a non-destructive Sinclair $\mathrm{IQ}^{\mathrm{Tm}}$ automated desktop firmness machine (51DFTB, International LTD, Jorrold, Bowthorpa, Norwich, NR5, 9D, England) at 0, 2, 4 and 6 days to ripening until were fully ripen. The firmness of each fruit was measured at three points along the equatorial region of the fruit and was expressed as Newton $(\mathrm{N})$. The same fruits were measured over time. 


\subsection{Statistical Analysis}

The analysis of variance (ANOVA) was performed with Genstat 16th version (VSN International, UK). The Least Significant Difference (LSD) was used to calculate the $p$-value at $95 \%$ confidence interval around the difference between treatments. Furthermore, Pearson correlation analysis was performed to determine the relationship between firmness, colour parameters, and exocarp pigments.

\section{Results and Discussion}

\subsection{Colour (Subjective and Objective Parameters)}

As "Hass" avocado fruit ripens, it is supposed to acquire a purple exocarp colour, which later develops to black colour while the green colour is degraded. In this study, there was a significant difference $(p=0.0228)$ in subjective (visual colour) between studied treatments during ripening. In general, there was an increase in exocarp visual colour for T1 $\left(10 \mu \mathrm{mol} \cdot \mathrm{L}^{-1}\right)$ and T2 $\left(100 \mu \mathrm{mol} \cdot \mathrm{L}^{-1}\right) \mathrm{MeJA}$ treatment when compared with control fruit (Figure 1(a)). In this study, MeJA treated fruit showed higher visual colour (5-purple), while control showed lower visual colour (4-violet) on day 6 at $25^{\circ} \mathrm{C}$. In terms of objective exocarp colour change, MeJA treated and control fruit showed no significant difference for $\mathrm{L}^{*}$ $(p=0.3997), C^{*}(p=0.0665)$ and $h^{\circ}(p=0.0647)$ during ripening (Figures 1 (b)-(d)). However, the objective exocarp colour parameters ( $\mathrm{L}^{*}, C^{*}$ and $h^{g}$ ) decreased for all the treatments during ripening. Moreover, control fruits showed higher $\mathrm{L}^{*}$ values than MeJA treated fruit on day 6 at $25^{\circ} \mathrm{C}$, which corresponded with green colour maintenance.

The $C^{*}$ values did not differ between MeJA treated and control fruit on day 6 at $25^{\circ} \mathrm{C}$. However, the $h^{\circ}$ values for control were higher when compared with MeJA treated fruit on day 6 at $25^{\circ} \mathrm{C}$. In addition, the correlations obtained between visual colour and objective colour parameters were negative and significant $(p<0.001)$, which could mean that exocarp colour change was dependent on decreased objective colour parameters ( $\mathrm{L}^{*}, C^{*}$ and $h^{9}$ ) (Table 1). Our results were in agreement with previous researchers on "Hass" avocado fruit [1] [2] [4] who found that objective exocarp colour parameters ( $L^{*}, C^{*}$ and $\left.h^{9}\right)$ decrease to their lowest values during ripening. Furthermore, objective exocarp colour parameters $\left(\mathrm{L}^{*}, C^{*}\right.$ and $\left.h^{9}\right)$ of MeJA treated fruit were lower than those of control fruit on days 4 and 6 at $25^{\circ} \mathrm{C}$. Such results indicated that MeJA treatment stimulated exocarp purple colour development for "Hass" avocado fruit during ripening. These results could be attributed to the role of MeJA in regulating anthocyanin biosynthesis and implied that an improved exocarp colour development was enhanced by MeJA treatment when compared with control fruit. Methyl jasmonate promotes anthocyanin biosynthesis by up-regulating the transcription of related genes [11]. This could be the reason for the total anthocyanin to be highly and positively correlated $(p<0.001)$ with cyanidin-3-O-glucoside for MeJA treated fruit but not for control fruit. 


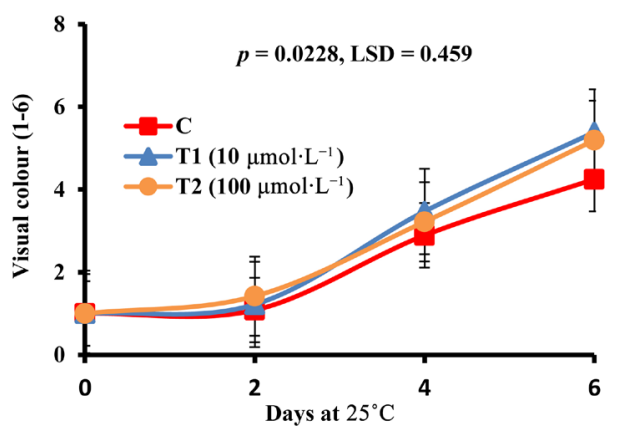

(a)

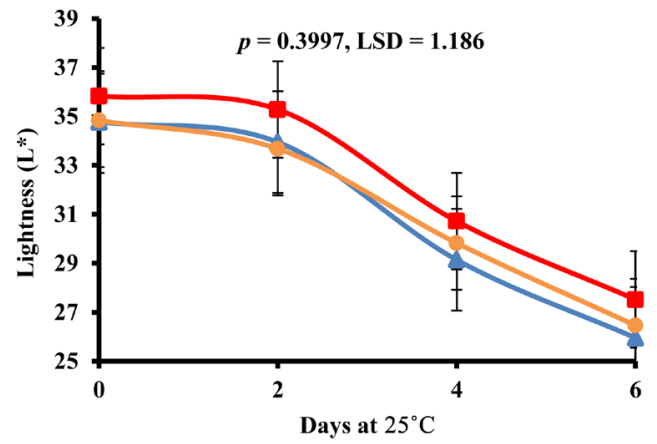

(b)

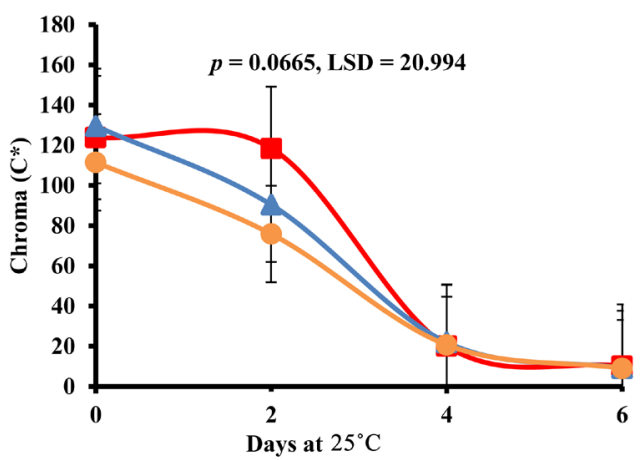

(c)

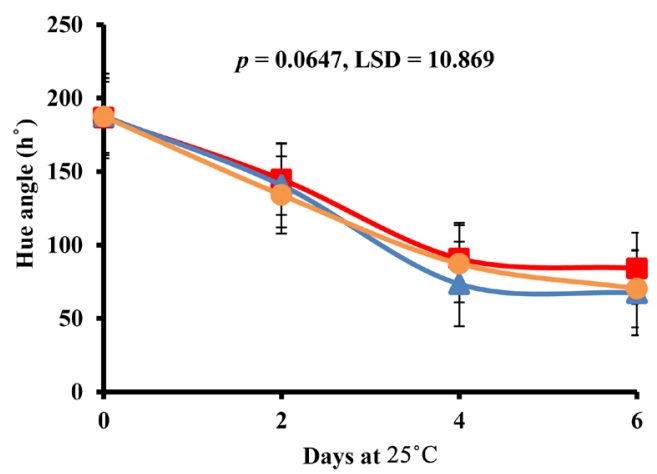

(d)

Figure 1. Change in (a) Visual colour; (b) $L^{\star}$ values; (c) $C^{\star}$ values; (d) $h^{\circ}$ values of control, T1 $\left(10 \mu \mathrm{mol} \cdot \mathrm{L}^{-1}\right)$ and T2 $\left(100 \mu \mathrm{mol} \cdot \mathrm{L}^{-1}\right) \mathrm{MeJA}$ treated "Hass" avocado fruit during ripening at $25^{\circ} \mathrm{C}$. Values are means of 3 replicates of 15 fruits. Error bars indicate $\pm \mathrm{SE}$ of means at $p \leq 0.05$. 
Table 1. Pearson correlation coefficient between objective colour parameters $\left(L^{*}, C^{*}, h^{\circ}\right)$ and subjective (visual colour) of "Hass" avocado fruit exocarp colour measurement/firmness and total anthocyanin, cyanidin-3-O-glucoside during ripening as influenced by control, $\mathrm{T} 1\left(10 \mu \mathrm{mol} \cdot \mathrm{L}^{-1}\right)$ and T2 $\left(100 \mu \mathrm{mol} \cdot \mathrm{L}^{-1}\right) \mathrm{MeJA}$ treatment.

\begin{tabular}{|c|c|c|c|}
\hline \multirow{2}{*}{ Correlation } & Control & $\mathrm{T} 1\left(10 \mu \mathrm{mol} \cdot \mathrm{L}^{-1}\right)$ & $\mathrm{T} 2\left(100 \mu \mathrm{mol} \cdot \mathrm{L}^{-1}\right)$ \\
\hline & \multicolumn{3}{|c|}{$R^{2}$} \\
\hline Firmness $\times L^{*}$ & $0.848^{\star * *}$ & $0.931^{* * *}$ & $0.906^{* * *}$ \\
\hline Firmness $\times C^{*}$ & $0.881^{\star * \star}$ & $0.972^{\star * *}$ & $0.959^{* * *}$ \\
\hline Firmness $\times h^{\circ}$ & $0.978^{\star * *}$ & $0.964^{* * *}$ & $0.985^{\star * *}$ \\
\hline Firmness $\times$ Visual & $-0.889^{* * *}$ & $-0.909^{* * *}$ & $-0.885^{\star * *}$ \\
\hline Visual $\times L^{*}$ & $-0.978^{\star * *}$ & $-0.988^{\star * *}$ & $-0.994^{\star * *}$ \\
\hline Visual $\times C^{*}$ & $-0.923^{\star * *}$ & $-0.922^{* * *}$ & $-0.896^{\star * *}$ \\
\hline Visual $\times h^{\circ}$ & $-0.896^{* * *}$ & $-0.887^{\star * *}$ & $-0.901^{\star * *}$ \\
\hline Visual $\times$ Total anthoc & $0.799^{* * *}$ & $0.846^{* * *}$ & $0.823^{* * *}$ \\
\hline Total anthoc $\times L^{*}$ & $-0.748^{\star * *}$ & $-0850^{* * *}$ & $-0.758^{\star * *}$ \\
\hline Total anthoc $\times C^{*}$ & $-0.819^{* * *}$ & $-0.905^{\star * *}$ & $-0.738^{\star * *}$ \\
\hline Total anthoc $\times h^{\circ}$ & $-0.967^{\star \star \star}$ & $-0.918^{\star * \star}$ & $-0.699^{*}$ \\
\hline Total anthoc $\times$ Cyandin-3-O-gluc & $0.532^{\mathrm{ns}}$ & $0.793^{\star * *}$ & $0.825^{\star * *}$ \\
\hline Cyandin-3-O-gluc $\times L^{*}$ & $-0.797^{\star * *}$ & $-0.941^{\star * *}$ & $-0.782^{\star * *}$ \\
\hline Cyandin-3-O-gluc $\times C^{*}$ & $-0.611^{\star *}$ & $-0.848^{* * *}$ & $-0.571^{\mathrm{ns}}$ \\
\hline Cyandin-3-O-gluc $\times h^{\circ}$ & $-0.579^{\star *}$ & $-0.798^{\star \star \star}$ & $-0.589^{\star}$ \\
\hline Cyandin-3-O-gluc $\times$ total chlor & $-0.944^{* * *}$ & $-0.625^{\star}$ & $-0.739^{\star * \star}$ \\
\hline Total chlor $\times L^{*}$ & $0.939^{\star * *}$ & $0.733^{* * *}$ & $0.967^{\star * *}$ \\
\hline Total chlor $\times C^{*}$ & $0.820^{\star * *}$ & $0.861^{\star * *}$ & $0.929^{* * *}$ \\
\hline Total chlor $\times h^{\circ}$ & $0.782^{\star * *}$ & $0.887^{\star * *}$ & $0.955^{\star * *}$ \\
\hline
\end{tabular}

${ }^{*}$ represent significant difference at ${ }^{*} p<0.05,{ }^{* *} p<0.01,{ }^{* *} p<0.001$ and $n s=$ not significant.

\subsection{Total Chlorophyll Content}

In this study, the total exocarp chlorophyll content in all fruit decreased continuously during ripening, however, different contents were observed among the three treatments (Figure 2). Our findings showed that T1 $\left(10 \mu \mathrm{mol} \cdot \mathrm{L}^{-1}\right) \mathrm{MeJA}$ concentration markedly accelerated this trend, with a significant difference $(p<$ 0.0001 ) between MeJA treated and control fruit. After 6 days at $25^{\circ} \mathrm{C}$, mean chlorophyll degradation for control fruit was $2.67 \mathrm{mg} 100 \mathrm{~g}^{-1} \mathrm{DW}$, while in T1 $\left(10 \mu \mathrm{mol} \cdot \mathrm{L}^{-1}\right)$ and T2 $\left(100 \mu \mathrm{mol} \cdot \mathrm{L}^{-1}\right)$ MeJA treated were 2.38 and $3.36 \mathrm{mg} 100 \mathrm{~g}^{-1}$ DW, respectively. However, fruit treated with T2 $\left(100 \mu \mathrm{mol} \cdot \mathrm{L}^{-1}\right)$ MeJA concentration exhibited higher total chlorophyll contents, while lower contents were found in control and T1 $\left(10 \mu \mathrm{mol} \cdot \mathrm{L}^{-1}\right)$ MeJA treated fruit after 4 and 6 days at $25^{\circ} \mathrm{C}$, respectively. Chlorophyll degradation for "Hass" avocado fruit often relates to colour development during ripening [1]. As the fruit ripen and soften, 


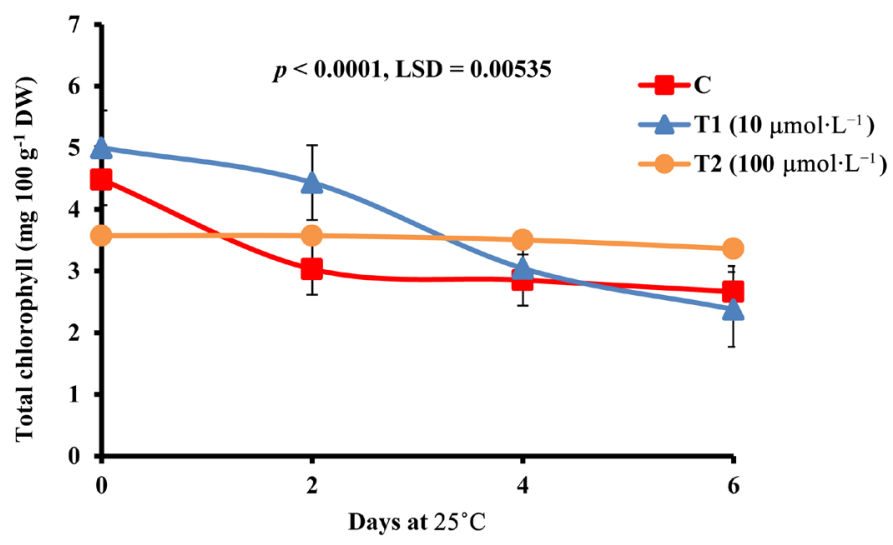

Figure 2. Change in total chlorophyll content of control, T1 $\left(10 \mu \mathrm{mol} \cdot \mathrm{L}^{-1}\right)$ and T2 $(100$ $\left.\mu \mathrm{mol} \cdot \mathrm{L}^{-1}\right) \mathrm{MeJA}$ treated "Hass" avocado fruit during ripening at $25^{\circ} \mathrm{C}$. Values are means of 5 fruits. Error bars indicate \pm SE of means at $p \leq 0.05$.

chlorophyll content is degraded, while anthocyanin accumulates in the exocarp, consequently, colour changes from green to purple [1] [2] [17]. In this study, chlorophyll degradation was lower in fruit treated with $\mathrm{T} 1\left(10 \mu \mathrm{mol} \cdot \mathrm{L}^{-1}\right) \mathrm{MeJA}$ than in T2 $\left(100 \mu \mathrm{mol} \cdot \mathrm{L}^{-1}\right)$ MeJA treated and control fruit. Accordingly, the change in chlorophyll content correlated $(p<0.001)$ with subjective (visual colour) and objective colour parameters $\left(L^{\star}, C^{*}\right.$ and $\left.h^{9}\right)$ during ripening in all three treatments (Table 1).

\subsection{Total Anthocyanin and Cyanidin-3-0-Glucoside}

Colour development of "Hass" avocado exocarp during ripening involves the accumulation of anthocyanin and cyanidin-3-O-glucoside [1]. A general significant $(p<0.0001)$ increase in total anthocyanin content was exhibited in all three treatments over the course of the ripening period. However, the increase in anthocyanin content was higher in MeJA treated when compared with the control fruit (Figure 3(a)). Notably, the total anthocyanin content for T1 $\left(10 \mu \mathrm{mol} \cdot \mathrm{L}^{-1}\right)$ and T2 $\left(100 \mu \mathrm{mol} \cdot \mathrm{L}^{-1}\right)$ MeJA treated fruit at the end of the ripening period (day

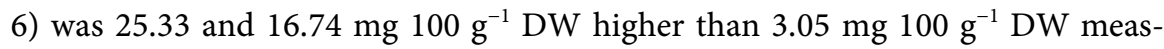
ured in control fruit, respectively. In relation to cyanidin-3-O-glucoside, a general significant $(p<0.0001)$ increasing trend was displayed in all three treatments during ripening (Figure $3(\mathrm{~b}))$. Moreover, T1 $\left(10 \mu \mathrm{mol} \cdot \mathrm{L}^{-1}\right)$ MeJA treated fruit exhibited higher exocarp cyanidin-3-O-glucoside content during ripening. In all treatments, cyanidin-3-O-glucoside content did not differ in the first days into ripening (day 0 to 2), however, increased over the remaining days (day 2 to 6 ) at $25^{\circ} \mathrm{C}$, with exceptional for T1 $\left(10 \mu \mathrm{mol} \cdot \mathrm{L}^{-1}\right)$ MeJA treated fruit.

The relationship between MeJA treatment and increased anthocyanin accumulation was also reported in other fruit species [18] [19]. It has been reported that preharvest and postharvest MeJA treatment increased activities of phenylalanine ammonia-lyase (PAL) enzyme which is responsible for polyphenol synthesis including anthocyanin [20]. For instance, treatment of MeJA combined 


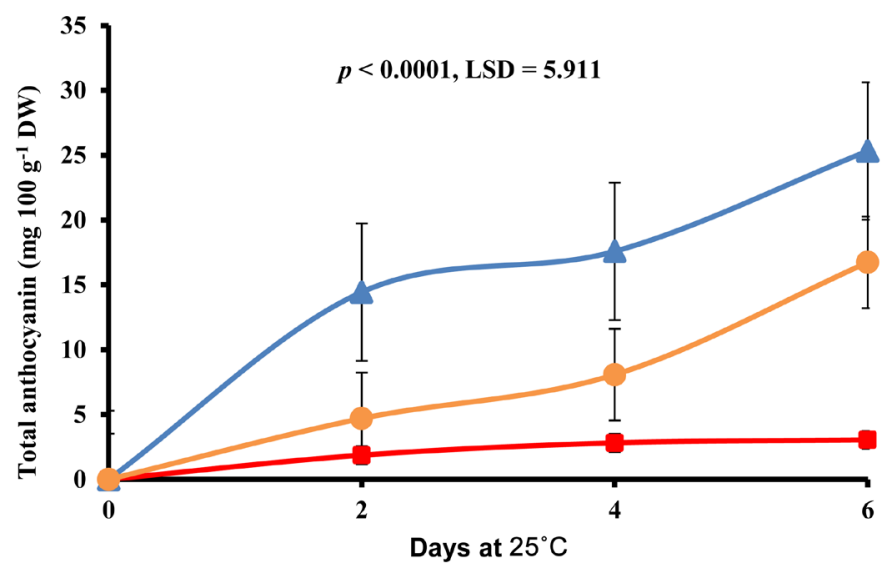

(a)

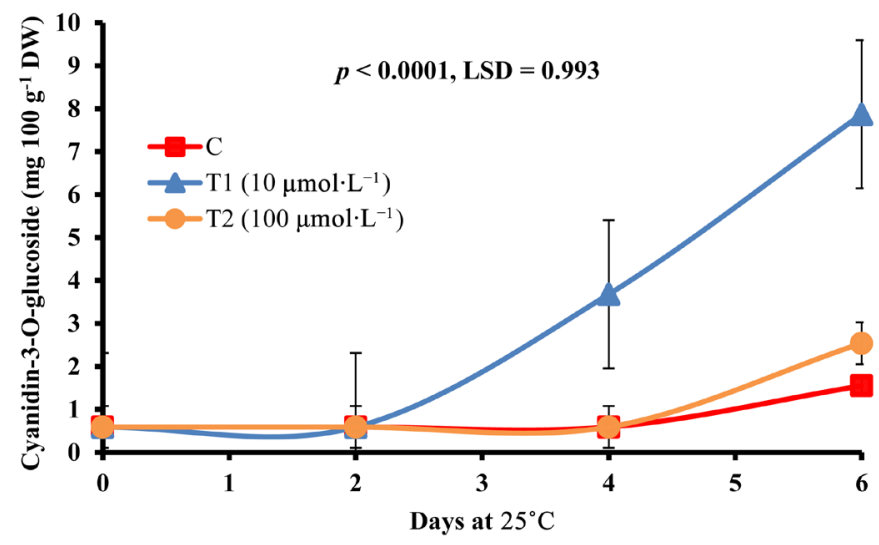

(b)

Figure 3. Change in (a) total anthocyanin and (b) cyanidin-3-O-glucoside content of control, T1 $\left(10 \mu \mathrm{mol} \cdot \mathrm{L}^{-1}\right)$ and T2 $\left(100 \mu \mathrm{mol} \cdot \mathrm{L}^{-1}\right) \mathrm{MeJA}$ treated "Hass" avocado fruit during ripening at $25^{\circ} \mathrm{C}$. Values are means of 5 fruits. Error bars indicate $\pm \mathrm{SE}$ of means at $p \leq$ 0.05 .

with sucrose stimulated phenylalanine ammonia-lyase (PAL), chalcone synthase (CHS), stilbene, UDP-glucose: Flavonoid-O-glucosyltransferase (UFGT), proteinase inhibitors and Chitinase, therefore, triggering the accumulation of anthocyanin in grapevine [21]. In strawberry and blackberry, bioactive compounds including; total phenolic, anthocyanin and carotenoids were enhanced by post-harvest MeJA treatment [19] [22]. In mango fruit, MeJA treatment induced higher PAL activity, in turn, increased phenolic and anthocyanin synthesis and accumulation [13]. In our current research work, MeJA supposedly induced PAL activity, and thereby, cyanidin-3-O-glucoside synthesis and accumulation, consequently, improved early matured "Hass" avocado exocarp colour development during ripening.

\subsection{Fruit Firmness}

Fruit firmness loss of avocado is an important ripeness indicator and directly affects shelf-life. A significant $(p=0.0371)$ decreasing trend in fruit firmness was 
found amongst all the treatments. In the present work, firmness loss was increased gradually with days to ripening, regardless of treatment (Figure 4). However, postharvest application with MeJA contributed collaboratively to accelerated firmness loss for "Hass" avocado fruit during ripening when compared with control fruit. Similar results have been reported by Cao et al. [23], who observed that firmness level decreased for loquat (Eriobotrya japonica Lindl.) fruit, regardless of treatment during storage. In the present study, fruit treated with MeJA exhibited the lowest firmness values throughout the days to ripening except at day 6 when compared with control. The fruit treated with T1 (10 $\left.\mu \mathrm{mol} \cdot \mathrm{L}^{-1}\right)$ and T2 $\left(100 \mu \mathrm{mol} \cdot \mathrm{L}^{-1}\right) \mathrm{MeJA}$ treated fruit had higher firmness values on day 6 compared to control. The accelerated firmness loss with the postharvest application of MeJA treatment may be due to the effect of MeJA on increasing activities of fruit softening enzymes mainly polygalacturonase (PG), cellulase and pectin methylesterase (PME) which account for hydrolysing glycosidic linkage in the cell wall integrity which is directly related to ripening and senescence. In some studies, contrary results have been reported for the effect of MeJA treatment on firmness where it was dependent on the fruit type [24] [25]. For instance, Baswal et al. [25] investigated the postharvest application of methyl jasmonate (MeJA), 1-Methylcyclopropene (1-MCP) and salicylic acid (SA) to extend the cold storage and maintain the quality of "Kinnow" mandarin (Citrus nobilis L. X C. deliciosa L.) fruit. The authors found that application of MeJA $\left(0.001 \mu \mathrm{mol} \cdot \mathrm{L}^{-1}\right), 1-\mathrm{MCP}\left(1.5 \mu \mathrm{L} \cdot \mathrm{L}^{-1}\right)$ and SA $\left(0.002 \mu \mathrm{mol} \cdot \mathrm{L}^{-1}\right)$ were effective to maintain fruit quality by decreasing weight loss, firmness, juice content and retarded the activities of enzymes mainly cellulase and PME. Reduced firmness loss by the inhibition of the activities of cell wall degrading enzymes such as cellulase, PG and PME and $\beta$-galactosidase has also been reported for postharvest application of MeJA in "Beauty" blueberry fruit [26].

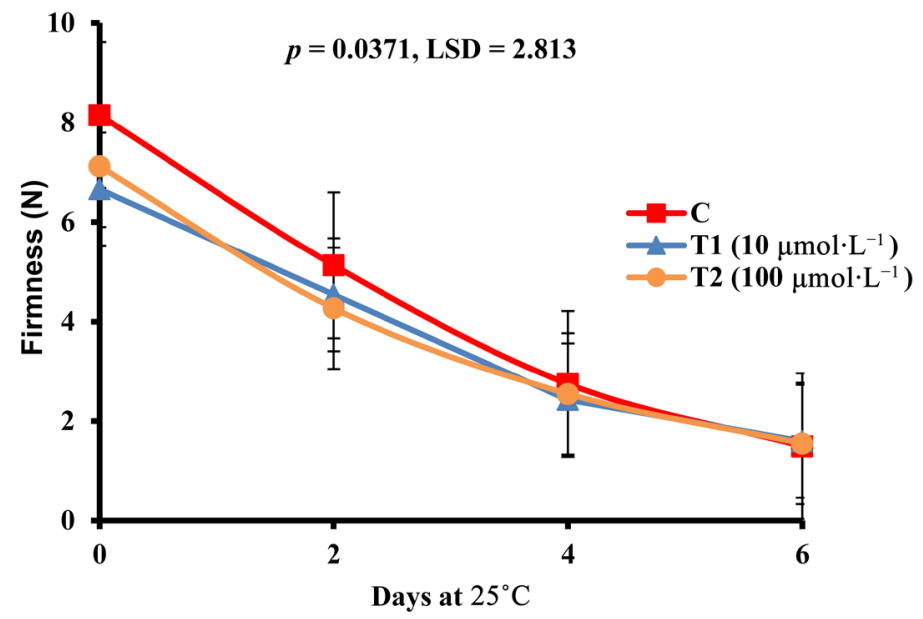

Figure 4. Change in firmness of control, T1 $\left(10 \mu \mathrm{mol} \cdot \mathrm{L}^{-1}\right)$ and $\mathrm{T} 2\left(100 \mu \mathrm{mol} \cdot \mathrm{L}^{-1}\right) \mathrm{MeJA}$ treated "Hass" avocado fruit during ripening at $25^{\circ} \mathrm{C}$. Values are means of 3 replicates of 15 fruits. Error bars indicate $\pm \mathrm{SE}$ of means at $p \leq 0.05$. 


\section{Conclusion}

This study revealed that MeJA treatment improved the exocarp colour development of "Hass" avocado fruit during ripening. The results demonstrate that post-harvest treatment with MeJA improved exocarp attributes such as colour chromaticity $\left(\mathrm{L}^{*}, C^{*} h^{\circ}\right.$ and visual colour) and pigments (total anthocyanin and cyanidin-3-O-glucoside) during ripening, therefore, can be recommended for avocado fruit.

\section{Acknowledgements}

The authors thank the Agricultural Sector Education Training Authority (AgriSeta) for financial supporting this study. The Agricultural Research Council-Tropical and Subtropical Crops, and the Tshwane University of Technology are for laboratory support and analysis.

\section{Conflicts of Interest}

The authors declare that they do not have any conflict of interest.

\section{References}

[1] Cox, K.A., McGhie, T.K., White, A. and Woolf, A.B. (2004) Skin Colour and Pigment Changes during Ripening of "Hass" Avocado Fruit. Postharvest Biology and Technology, 31, 287-294. https://doi.org/10.1016/j.postharvbio.2003.09.008

[2] Mathaba, N., Mafeo, T.P. and Kruger, F.J. (2015) The Skin Colouring Problem of "Hass" Avocado Fruit During Ripening. South African Avocado Growers Association Yearbook, 38, 51-57.

[3] Donetti, M. and Terry, L.A. (2014) Biochemical Markers Defining Growing Area and Ripening Stage of Imported Avocado Fruit cv. Hass. Journal of Food Composition and Analysis, 34, 90-98. https://doi.org/10.1016/j.jfca.2013.11.011

[4] Ashton, O.B., Wong, M., McGhie, T.K., Vather, R., Wang, Y. and Requejo-Jackman, C. (2006) Pigments in Avocado Tissue and Oil. Journal of Agricultural and Food Chemistry, 54, 10151-10158. https://doi.org/10.1021/jf061809j

[5] Öztürk, B., Özkan, Y. and Yildiz, K. (2014) Methyl Jasmonate Treatments Influence Bioactive Compounds and Red Peel Color Development of Braeburn Apple. Turkish Journal of Agriculture and Forestry, 38, 688-699. https://doi.org/10.3906/tar-1312-43

[6] Seo, J., Yi, G., Lee, J.G., Choi, J.H. and Lee, E.J. (2020) Seed Browning in Pepper (Capsicum annuum L.) Fruit during Cold Storage is Inhibited by Methyl Jasmonate or Induced by Methyl Salicylate. Postharvest Biology and Technology, 166, 111-210. https://doi.org/10.1016/j.postharvbio.2020.111210

[7] Flores, G., Blanch, G.P., and del Castillo, M.L.R. (2015) Postharvest Treatment with $(-)$ and (+)-Methyl Jasmonate Stimulates Anthocyanin Accumulation in Grapes. LWT-Food Science and Technology, 62, 807-812. https://doi.org/10.1016/j.lwt.2014.12.033

[8] Wang, H., Wu, Y., Yu, R., Wu, C., Fan, G. and Li, T. (2019) Effects of Postharvest Application of Methyl Jasmonate on Physicochemical Characteristics and Antioxidant System of the Blueberry Fruit. Scientia Horticulturae, 258, Article No. 108785. 
https://doi.org/10.1016/j.scienta.2019.108785

[9] Fan, L., Shi, J., Zuo, J., Gao, L., Lv, J. and Wang, Q. (2016) Methyl Jasmonate Delays Postharvest Ripening and Senescence in the Non-Climacteric Eggplant (Solanum melongena L.) Fruit. Postharvest Biology and Technology, 120, 76-83. https://doi.org/10.1016/j.postharvbio.2016.05.010

[10] Liu, H., Meng, F., Miao, H., Chen, S., Yin, T. and Hu, S. (2018) Effects of Postharvest Methyl Jasmonate Treatment on Main Health-Promoting Components and Volatile Organic Compounds in Cherry Tomato Fruits. Food Chemistry, 263, 194-200. https://doi.org/10.1016/j.foodchem.2018.04.124

[11] García-Pastor, M.E., Serrano, M., Guillén, F., Castillo, S., Martínez-Romero, D. and Valero, D. (2019) Methyl Jasmonate Effects on Table Grape Ripening, Vine Yield, Berry Quality and Bioactive Compounds Depend on Applied Concentration. Scientia Horticulturae, 247, 380-389. https://doi.org/10.1016/j.scienta.2018.12.043

[12] Wang, S.Y., Bowman, L. and Ding, M. (2008) Methyl Jasmonate Enhances Antioxidant Activity and Flavonoid Content in Blackberries (Rubus sp.) and Promotes Antiproliferation of Human Cancer Cells. Food Chemistry, 107, 1261-1269.

https://doi.org/10.1016/j.foodchem.2007.09.065

[13] Muengkaew, R., Chaiprasart, P. and Warrington, I. (2016) Changing of Physiochemical Properties and Color Development of Mango Fruit Sprayed Methyl Jasmonate. Scientia Horticulturae, 198, 70-77. https://doi.org/10.1016/j.scienta.2015.11.033

[14] McGuire, R.G. (1992) Reporting of Objective Color Measurements. HortScience, 27, 1254-1255. https://doi.org/10.21273/HORTSCI.27.12.1254

[15] Lichtenthaler, H.K. (1987) Chlorophylls and Carotenoids: Pigments of Photosynthetic Biomembranes. Methods in Enzymology, 350-382. https://doi.org/10.1016/0076-6879(87)48036-1

[16] Giusti, M.M. and Wrolstad, R.E. (2001) Characterization and Measurement of Anthocyanins by UV-Visible Spectroscopy. Current Protocols in Food Analytical Chemistry, F1.2.1-F1.2.13. https://doi.org/10.1002/0471142913.faf0102s00

[17] Mathaba, N., Mathe, S., Mafeo, T.P., Tesfay, S.Z. and Mlimi, J. (2017) Complexities of 'Hass' Avocado Skin Colour Change During Ripening South African Avocado Growers Association Yearbook, 40, 129-132.

[18] Díaz-Mula, H., Zapata, P., Guillén, F., Martínez-Romero, D., Castillo, S. and Serrano M. (2009) Changes in Hydrophilic and Lipophilic Antioxidant Activity and Related Bioactive Compounds during Postharvest Storage of Yellow and Purple Plum Cultivars. Postharvest Biology and Technology, 51, 354-363.

https://doi.org/10.1016/j.postharvbio.2008.09.007

[19] Sayyari, M., Babalar, M., Kalantari, S., Martínez-Romero, D., Guillén, F. and Serrano, M. (2011) Vapour Treatments with Methyl Salicylate or Methyl Jasmonate Alleviated Chilling Injury and Enhanced Antioxidant Potential During Postharvest Storage of Pomegranates. Food Chemistry, 124, 964-970.

https://doi.org/10.1016/j.foodchem.2010.07.036

[20] Saracoglu, O., Ozturk, B., Yildiz, K. and Kucuker, E. (2017) Pre-Harvest Methyl Jasmonate Treatments Delayed Ripening and Improved Quality of Sweet Cherry Fruits. Scientia Horticulturae, 226, 19-23.

https://doi.org/10.1016/j.scienta.2017.08.024

[21] Belhadj, A., Telef, N., Saigne, C., Cluzet, S., Barrieu, F. and Hamdi, S. (2008) Effect of Methyl Jasmonate in Combination with Carbohydrates on Gene Expression of 
PR Proteins, Stilbene and Anthocyanin Accumulation in Grapevine Cell Cultures. Plant Physiology and Biochemistry, 46, 493-499. https://doi.org/10.1016/j.plaphy.2007.12.001

[22] Chanjirakul, K., Wang, S.Y., Wang, C.Y. and Siriphanich, J. (2006) Effect of Natural Volatile Compounds on Antioxidant Capacity and Antioxidant Enzymes in Raspberries. Postharvest Biology and Technology, 40, 106-115.

https://doi.org/10.1016/j.postharvbio.2006.01.004

[23] Cao, S., Zheng, Y., Wang, K., Jin, P. and Rui, H. (2009) Methyl Jasmonate Reduces Chilling Injury and Enhances Antioxidant Enzyme Activity in Postharvest Loquat Fruit. Food Chemistry, 115, 1458-1463.

https://doi.org/10.1016/j.foodchem.2009.01.082

[24] Reyes-Díaz, M., Lobos, T., Cardemil, L., Nunes-Nesi, A., Retamales, J. and Jaakola, L. (2016) Methyl Jasmonate: An Alternative for Improving the Quality and Health Properties of Fresh Fruits. Molecules, 21, 567. https://doi.org/10.3390/molecules21060567

[25] Baswal, A., Dhaliwal, H., Singh, Z., Mahajan, B. and Gill, K. (2020) Postharvest Application of Methyl Jasmonate, 1-Methylcyclopropene and Salicylic Acid Extends the Cold Storage Life and Maintain the Quality of "Kinnow" Mandarin (Citrus nobilis L. X C. deliciosa L.) Fruit. Postharvest Biology and Technology, 161, Article No. 111064. https://doi.org/10.1016/j.postharvbio.2019.111064

[26] Wang, H., Cheng, X., Wu, C., Fan, G., Li, T. and Dong, C. (2021) Retardation of Postharvest Softening of Blueberry Fruit by Methyl Jasmonate is Correlated with Altered Cell Wall Modification and Energy Metabolism. Scientia Horticulturae, 276, Article No. 109752. https://doi.org/10.1016/j.scienta.2020.109752 